Bangladesh Journal of Anatomy January 2012, Vol. 10 No. 1 pp 23-26

\title{
Study of Internal Diameter of the Common Bile Duct in Human Cadaver
}

\author{
Laila Farzana Khan ${ }^{1}$, Humaira Naushaba ${ }^{2}$, M. Tanveer Hossain Parash ${ }^{3}$, Rubina Qasim ${ }^{4}$, \\ Shams-E-Tabriz ${ }^{5}$
}

\begin{abstract}
Context: The common bile duct is formed near the porta hepatis by the union of cystic \& common hepatic duct. The diameter of the common bile duct tends to increase with age but it may dilate significantly in obstructive disease of the biliary passages. So internal diameter of the common bile duct has an important implication for proper diagnosis and management of biliary diseases.
\end{abstract}

Study design: Cross sectional, analytical study.

Place and period of study: Department of Anatomy, Sir Salimullah Medical College (SSMC), Dhaka from July 2010 to June 2011.

Materials: 62 postmortem human extra hepatic biliary apparatus were collected from unclaimed dead bodies that were under examination in the department of Forensic Medicine of Dhaka Medical College, Dhaka and Sir Salimullah Medical College (SSMC), Dhaka.

Methods: The samples were divided into three age groups i.e. group A (10-20 years), group $B$ (21-40 years) and group $C$ (41-70 years).

Result: Morphologically, the mean ( $\pm S D$ ) internal diameter of the common bile duct was $3.06+0.06 \mathrm{~mm}$ in group $A, 4.74+0.57 \mathrm{~mm}$ in group $B$ and $5.99+0.60 \mathrm{~mm}$ in group $C$. The differences in mean diameter of the common bile duct were found statistically highly significant $(P<0.001)$ when compared between $A$ vs $B, A$ vs $C$ and $B$ vs $C$ groups. Statistically positive correlation was found between age \& internal diameter of the common bile duct which was highly significant $(r=+0.873, P<0.001)$.

Conclusion: This study revealed an age related change in the diameter of the common bile duct

Keywords: Common bile duct, Diameter, Aging

\section{Introduction:}

The common bile duct forms in the free edge of the lesser omentum by the union of the cystic and common hepatic duct. The length of the common bile duct is $6-8 \mathrm{~cm}$ \& the diameter is about 4-6 $\mathrm{mm}^{1}$. It empties into the second part of the duodenum in common with or alongside the main

1. Assistant Professor, Department of Anatomy, Dhaka National Medical College, Dhaka.

2. Professor and Head, Department of Anatomy, Sir Salimullah Medical College, Mitford, Dhaka.

3. Assistant Professor (c.c), Department of Anatomy, Satkhira Medical College, Satkhira.

4. Assistant Professor, Department of Anatomy, East West Medical College, Dhaka.

5. Assistant Professor (c.c), Department of Anatomy, Sheikh Sayera khatun Medical College, Gopalganj.

Correspondence: Dr. Laila Farzana Khan pancreatic duct and forms the hepatopancreatic ampulla (of Vater) which opens into the posteromedial wall of the second part of the duodenum at the summit of the major duodenal papilla situated $8-10 \mathrm{~cm}$ distal to the pylorus ${ }^{2}$. The union of the two ducts somewhat varies between individuals ${ }^{3}$. The wall of the biliary duct consists of outer fibrous and inner mucosal layers. The epithelium is columnar and there are numerous mucous glands in the duct wall ${ }^{4}$. The common bile duct gradually dilates with age. It has been suggested that bile duct dilatation may predispose to bile stasis and thus promote stone formation ${ }^{5}$. However, there is limited standard measurement data available on the normal diameter of the common bile duct in Bangladeshi people. The aim of this 
study was to determine normal diameter and age related changes in common bile duct of Bangladeshi people.

\section{Materials \& Methods:}

The samples of human extra hepatic biliary apparatus were collected from unclaimed dead bodies that were under examination in the department of Forensic Medicine of Dhaka Medical College, Dhaka and Sir Salimullah Medical College (SSMC), Dhaka from July 2010 to June 2011. For the convenience of the study of various changes in relation to age, the collected samples were divided into three age groups i.e. group A (10-20 years), group B (21-40 years) and group C (41-70 years) (Table-I).

\section{Table-I}

Age distribution of different study groups ((according to Sarkar 6 , 2010)

\begin{tabular}{ccc}
\hline Groups & $\begin{array}{c}\text { Age range } \\
\text { (in years) }\end{array}$ & $\begin{array}{c}\text { No. of samples } \\
(\mathrm{n}=62)\end{array}$ \\
\hline A & $10-20$ & 14 \\
$B$ & $21-40$ & 30 \\
C & $41-70$ & 18 \\
\hline
\end{tabular}

\section{Morphological method:}

The internal diameter of the common bile duct was measured with the help of two 'mm' scale which was made by a computer software named Adobe illustrator 10 versions. One scale was $12 \mathrm{~mm}$ horizontal and another scale was $6 \mathrm{~mm}$ vertical in which $0.5 \mathrm{~mm}$ and $1 \mathrm{~mm}$ distance were marked. Then it was printed on a transparent sheet. The common bile duct was cut transversely with scissor as thin as possible and three sections were taken from proximal, middle and distal portion. The cut sections were placed over the scale like that the center of the lumen was placed approximately over the center of the scale. Then under electric magnifying glass, the internal diameter of the common bile duct was calculated in $\mathrm{mm}$ by taking average of transverse and vertical measurements (Fig 1).
Ethical Clearance: The study was approved by the ethical review commitee of Sir Salimullah Medical College
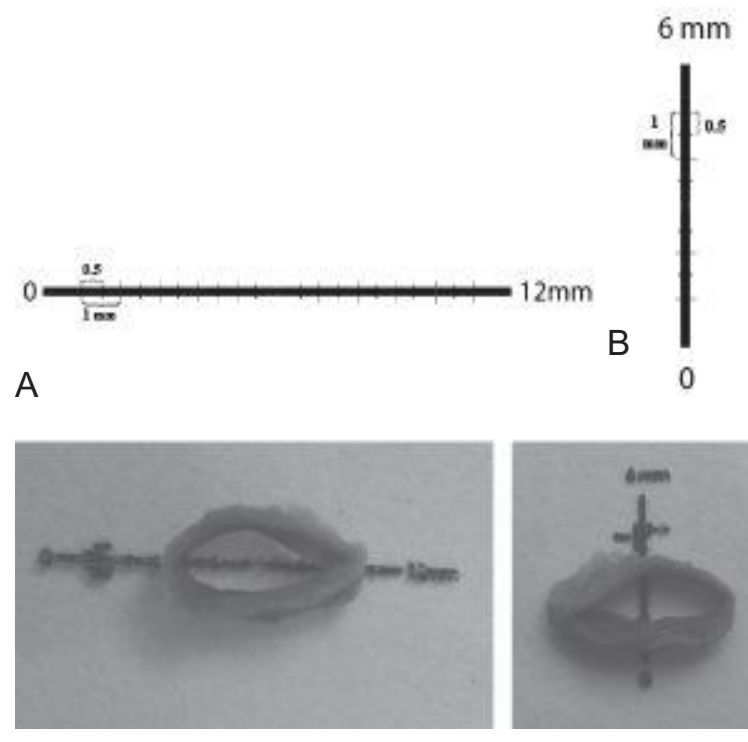

C

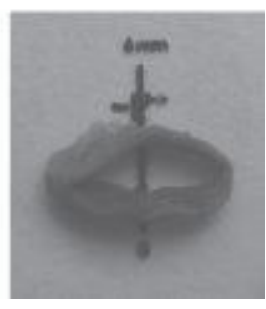

D

Fig 1 A. Photograph showing the $12 \mathrm{~mm}$ horizontal scale.

B. Photograph showing the $6 \mathrm{~mm}$ vertical scale.

C. Photograph showing the cut sections of the common bile duct placed over the horizontal scale printed on transparent sheet.

D. Photograph showing the cut sections of the common bile duct placed over the vertical scale printed on transparent sheet.

\section{Result:}

In the present study, the mean ( \pm SD) internal diameter of the common bile duct was $3.06+0.06$ $\mathrm{mm}$ in group $\mathrm{A}, 4.74+0.57 \mathrm{~mm}$ in group $B$ and $5.99+0.60 \mathrm{~mm}$ in group $\mathrm{C}$. The differences in mean diameter of the common bile duct were found statistically highly significant $(P<0.001)$ between $A$ vs $B, A$ vs $C$ and $B$ vs $C$ groups (Table II \& Fig. -2 ). Statistically positive correlation was found between age \& internal diameter of the common bile duct which was highly significant $(r=+0.873, P<0.001)$ (Fig 3). 
Table II

Mean $( \pm S D$ ) internal diameter of the common bile duct in different age groups

\begin{tabular}{lccc}
\hline Age group & $\begin{array}{c}\text { Diameter (mm) } \\
\text { Mean } \pm \text { SD }\end{array}$ & $\begin{array}{c}\text { Age group } \\
\text { comparison }\end{array}$ & $\begin{array}{c}\mathrm{P} \\
\text { value }\end{array}$ \\
\hline $\mathrm{A}(10-20 \mathrm{yrs})$ & $\begin{array}{c}3.06 \pm 0.06 \\
(2.933 .15)\end{array}$ & A vs B & $\mathrm{P}<0.001^{* * *}$ \\
& & & \\
B (21-40yrs) & $\begin{array}{l}4.74 \pm 0.57 \\
\end{array}$ & A vs C & $\mathrm{P}<0.001^{* * *}$ \\
& $(3.395 .41)$ & & \\
C (41-70yrs) & $5.99 \pm 0.60$ & B vs C & $\mathrm{P}<0.001^{* * *}$ \\
& $(4.986 .94)$ & & \\
\hline
\end{tabular}

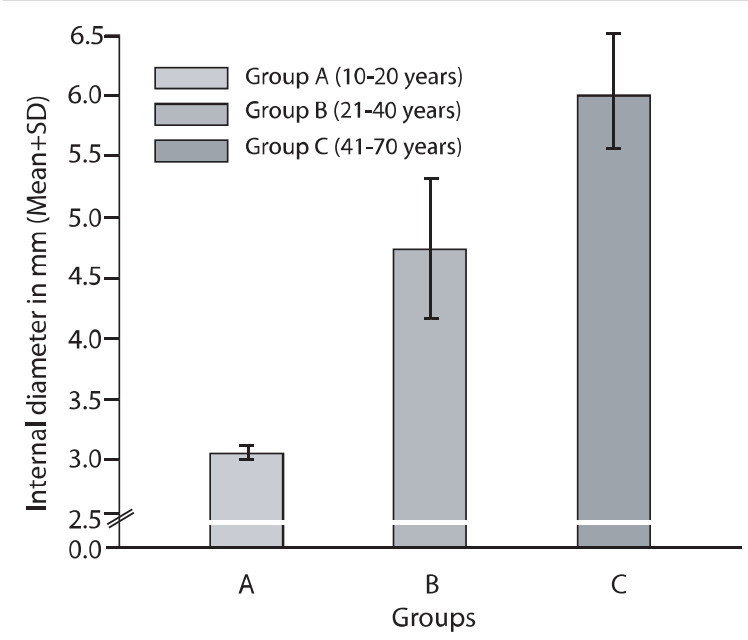

Fig.-2: Internal diameter of the common bile duct in different age groups

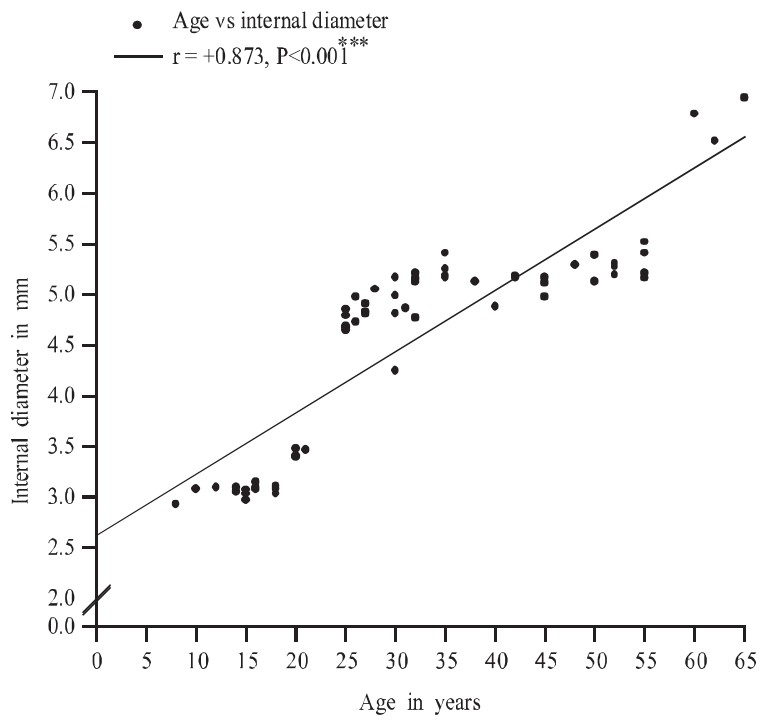

Fig.-3: Relationship between age and internal diameter of common bile duct

\section{Discussion:}

In the present study, the highest mean diameter of the common bile duct was found in group $C$ and lowest in group $A$. The values were found highly significant $(P<0.001)$ when group $A$ was compared with group $B$, group $A$ with group $C$ and group $B$ with group $\mathrm{C}$. The internal diameter of the common bile duct showed positive correlationship with age which was highly significant $(P<0.001)$. The mean diameter of the common bile duct corresponded with those of Brunicardi ${ }^{7}$ (2010), Standring ${ }^{1}$ (2008), Williams $^{8}$ (2008), Moore \& Dalley ${ }^{2}$ (2006) and Rumack \& Wilson ${ }^{9}$ (2005). Bacher et al ${ }^{10}$ in 2003 found a significant correlation between diameter of the common bile duct and age. They found that the duct gradually dilates by $0.04 \mathrm{~mm}$ per year. In 1993 Khaliil ${ }^{11}$ reported $3.16 \mathrm{~mm}$ the mean internal diameter of the common bile duct at the age of 2550 years which was lower than the mean diameter of the common bile duct of group $B$ and group $C$ of the present study. This dissimilarity might be due to different procedure of sample fixation and measurement of variables.

\section{References:}

1. Standring S. Gray's Anatomy. The Anatomical Basis of Clinical Practice. $40^{\text {th }}$ ed. London: Churchill Livingstone; 2008. 1177-81.

2. Moore KL, Dalley II AF. Clinically oriented anatomy. $5^{\text {th }}$ ed. Philadelphia: Lippincott Williams \& Wilkins; 2006. 301-04.

3. Gore RM, Levine MS, Laufer I. Textbook of gastrointestinal radiology $\mathrm{Vol} 2.5^{\text {th }}$ ed. Philadelphia: W B Saunders; 1994. 1570-71.

4. Ross MH, Romrell LJ, Kaye GI. Histology: a text and atlas. $5^{\text {th }}$ ed. Baltimore: Williams and Wilkins; 2006. p. 543-47.

5. Park JS, Lee DH, Jeong S, Cho SG. Determination of diameter and angulation of the normal common bile duct using Multidetector Computed Tomography. Gut and Liver Dec 2009; vol. 3 No. 4: 306-10.

6. Sarkar N. Role of ultrasonography in the diagnosis of common gallbladder problems (M Phil thesis). Dhaka: Bangabandhu Sheikh Mujib Medical University. 2010. 
7. Brunicardi FC. Schwartz's Principles of surgery. $9^{\text {th }}$ ed. New York: Mc Graw Hill; 2010. 1136-42.

8. Williams NS, Bulstrode CJK, O'connel PR. Bailey \& Love's short practice of surgery. $25^{\text {th }}$ ed. London: Hodder Arnold; 2008. 1120.

9. Rumack C, Wilson S, Charbone J. Diagnostic ultrasound. $3^{\text {rd }}$ ed. Missouri: Mosby; 2005. 1234-36.
10. Bacher GN, Cohen M, Belenky A, Atar E, Gideon S. Effect of aging on the adult extra hepatic bile duct a sonographic sudy. J Ultrasound Med 2003; 22 (4): 879-82.

11. Khalil M. A comparative anatomical study of the extra hepatic biliary apparatus in goat, cow and men (M Phil thesis). Dhaka: University of Dhaka. 